\title{
Plan Común
}

Parque Városliget, Budapest, Hungría

2014 (Concurso y proyecto)

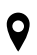

If the city is a device that allows to increase the market value -utility- of private property, architecture could counteract this process by creating useless value through collective public spaces. This is the position that Plan Común exemplifies in the project for two Museums in Hungary, proposing to use the transformative potential of architecture to create common spaces that remain outside the market's dynamics.

KEYWORDS · public space, commonality, competition, grid, park

Plan Común [Common Plan] was founded in 2012, a year after the reorganization of the social movements in Chile. Since then we have closely followed the recent processes of transformation and empowerment of the local and global society with the understanding that architecture cannot be far removed from these changes.

Designed as ideological devices from a neoliberal bias, contemporary cities tend to underestimate the value of public life and fragment collective living. Events like the Arab Spring, the indignados in Spain, or the protests in Taksim Square are excuses for government agencies -often infiltrated by transnational capital- to exert more control and restrict potential public assemblies. The blackmail of Grecian Eurocrats -which violates the sovereign rights of its citizens- is another example of how transnational capital affects our daily lives.

The crisis of public space is shared by thousands of cities around the world: the public sphere has been abandoned by the urban designs and dubious politics mandated almost exclusively by the flow of capital. This forces us to live in an environment of continuous crisis, because the assembly and organization of the public sphere directly threatens the accumulation of capital.

To achieve commonality in architecture it is essential to take up an anti-neoliberal leftist political project removed from private interests. We have grown accustomed to living fragmented lives, subjected to a complex structure designed by and for the few and their well-being. We need to rescue the political project of Latin American architects like Miguel Lawner, Fernando Castillo Velasco, João Vilanova Artigas or Lina Bo Bardi.

Personal creative pursuits are not enough to overcome these impositions from above -even if they are valuable contributions to the discipline-. We must organize, be militant and join the transformative processes of society as architects: to predispose ourselves to connect with the common good and project a long-term vision with a broad impact.

We're not just talking about intentions but methodologies as well. At every opportunity we must ask ourselves how we can define and enhance public space. We use the project explicitly in favor of collective spaces and look for extra space that cannot be conceptualized through 


\begin{tabular}{|c|}
\hline Arquitectos / Architects \\
\hline $\begin{array}{l}\text { Plan Común Arquitectos | Felipe De Ferrari, Diego Grass, } \\
\text { Kim Courreges, Marcelo Cox }\end{array}$ \\
\hline Arquitectos asociados / Associated architects \\
\hline Claudio Baladrón, Magdalena Besomi \\
\hline Colaboradores / Collaborators \\
\hline $\begin{array}{l}\text { Tyrene Calvesbert, Thomas Batzenschlager, } \\
\text { Kotaro Shimada, Costanza Zeni }\end{array}$ \\
\hline Ubicación / Location \\
\hline $\begin{array}{l}\text { Parque Városliget, Budapest, Hungría / } \\
\text { Városliget Park, Budapest, Hungary }\end{array}$ \\
\hline Cálculo estructural / Structural engineering \\
\hline Mast \\
\hline Proyecto de paisajismo / Landscaping project \\
\hline Jadue + Livingstone \\
\hline Proyecto de sustentabilidad / Sustainability Project \\
\hline$B+v$ Arquitectos \\
\hline Proyecto de movilidad / Mobility Project \\
\hline Pedaleable \\
\hline Proyecto de iluminación / Lighting Project \\
\hline Estudio PAR \\
\hline Materiales / Materials \\
\hline Hormigón armado y ladrillo / Reinforced concrete, brick \\
\hline $\begin{array}{l}\text { Terminaciones interiores y exteriores / Madera, vidrio, } \\
\text { policarbonato / Wood, glass, polycarbonate }\end{array}$ \\
\hline Superficie construida / Built area \\
\hline $2.660 \mathrm{~m}^{2}\left(1.330 \mathrm{~m}^{2}+1.330 \mathrm{~m}^{2}\right)$ \\
\hline Año de Proyecto / Project year \\
\hline 2014 \\
\hline Imágenes / Renders \\
\hline Plan Común Arquitectos \\
\hline
\end{tabular}
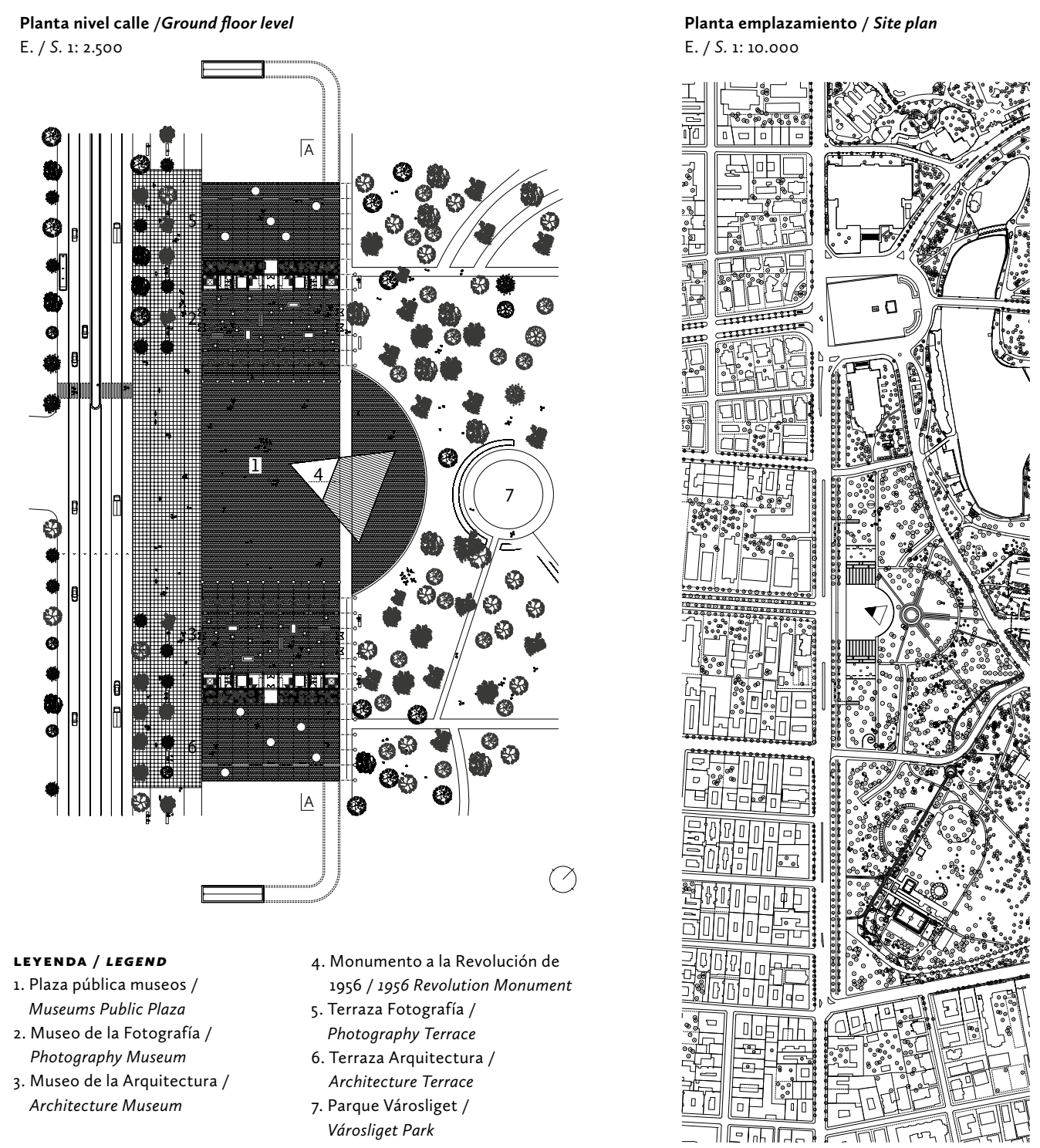

Corte AA / AA Section E. 1: S. 1.250

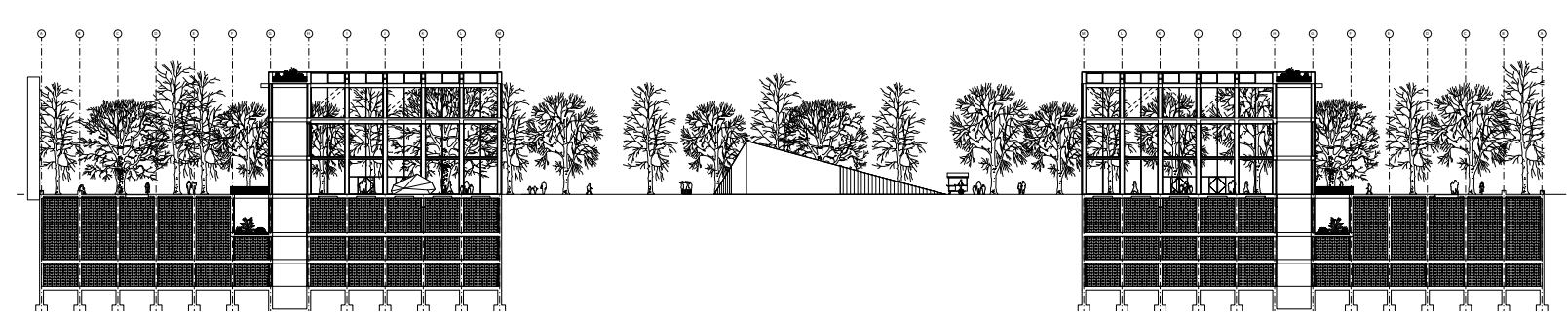

the wishes of the client or the competition's brief (as they tend to institutionalize or commercialize everything). The transformative project of society is urgent, which forces us to concentrate on what is structural to the project: its revolutionary potential as an antidote to the leftovers offered to us by neoliberalism.

\section{PROJECT}

Budapest is subjected to the same pressures from international capital that Santiago or any other city suffers: forces that push for the surrender -with both hands up- of each one of the remaining pockets of a city's public resources. Spaces and things that should be available to all are taken as private property -water, views, recreational spaces, etc.-.

The Liget Budapest series of simultaneous competitions (2014-2015) is part of an initiative where the State of Hungary sought to activate the oldest public park in the world with cultural programs. We participated in one of the four calls where the commission was to design the Hungarian Museums of Architecture and Photography. From the beginning we 


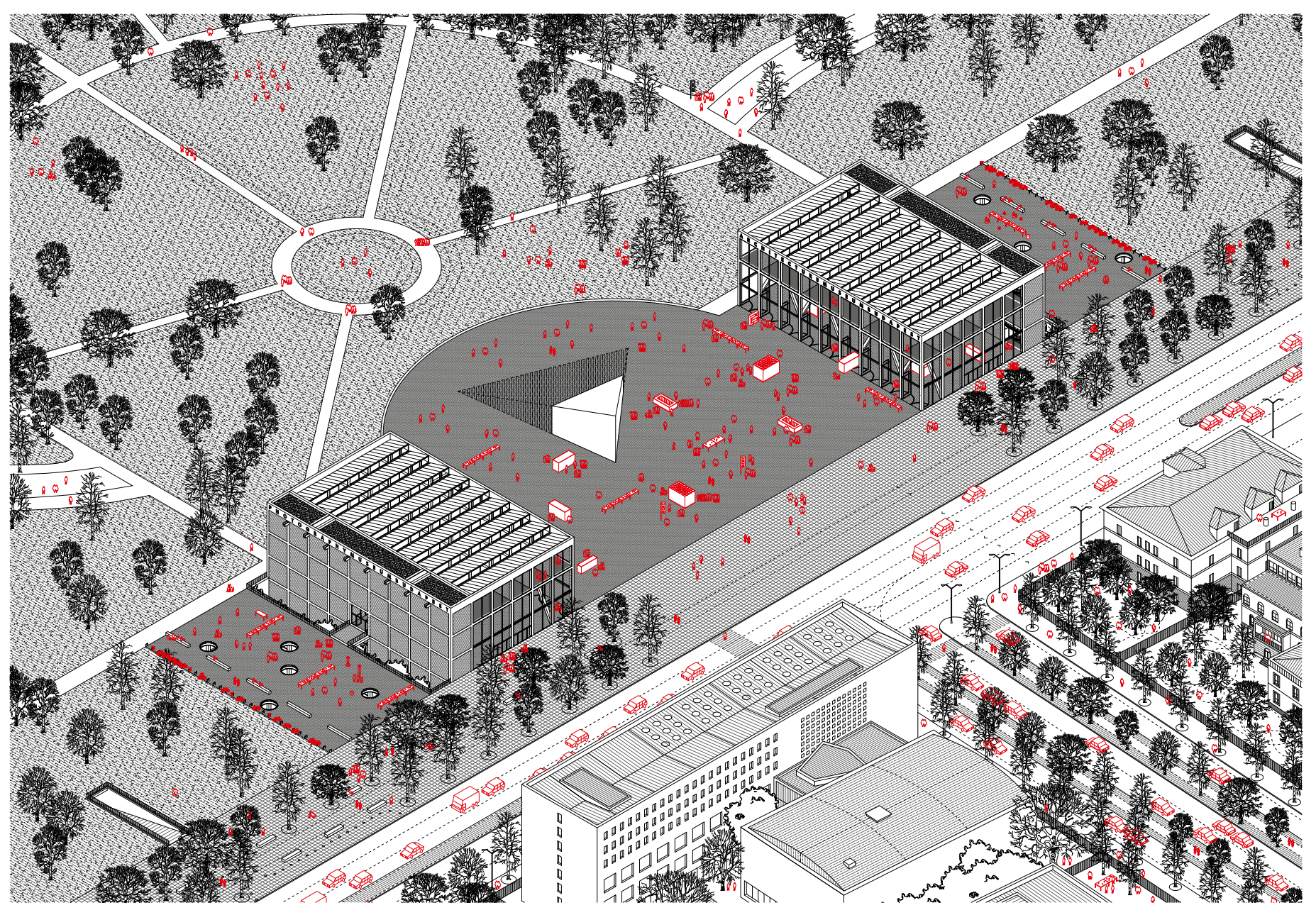

Isométrica / Isometric

S. E. / N.S.

concentrated on specifying its shared identity, maximizing meeting spaces, and promoting direct relationships between both institutions.

We are talking about a self-imposed condition where the museums and their surroundings are understood as a single unit (including the Revolution Monument of 1956, the circle, and its connections with the park). This is achieved through the use of a single organizing principle: a structural grid, austere and effective at managing the interior and exterior spaces, that adjusts to the specific needs of each space or program to create a single identity for the whole.

Both museums have the same volume of $16 \mathrm{~m}$ (high) and $25 \mathrm{~m}$ (wide) $\times 45 \mathrm{~m}$ (long) with their main facades facing each other located perpendicular to Dózsa György Avenue and the pedestrian walkway projected for the park. The change in orientation proposed by the new park's master plan (2013) -suggesting that both museums be elongated blocks aligned with Dózsa György- is the first operation in favor of collective enjoyment: the two buildings collaborate between each other to create an entrance plaza to the park of $80 \times 50 \mathrm{~m}$.

Finally, the programs required by the commission are distributed over two levels: the administrative areas are elevated above the street level, while the technical and exhibition areas -requiring artificial light- are three levels below ground (reducing energy consumption). Between these levels an extra space appears -neither requested nor conceptualized in the commission- of $9000 \mathrm{~m} 3$ in each museum. These covered public volumes - of unique spatial conditions in the context of Budapest- are experimental fields awaiting appropriation by the citizens and joint agendas of the two museums. ARQ 


\section{FELIPE DE FERRARI}

<fdf@030otv.com>

Architect, Pontificia Universidad Católica de Chile (2010). Cofounder of озоотV, OnArchitecture and Plan Común Arquitectos. Co-editor of the books ARQ Docs Pier Vittorio Aureli (2014) and ARQ Docs Atelier Bow-Wow (2015). He has lectured at the Barcelona Institute of Architecture (2009), the Center for Contemporary Culture in Barcelona (2011), the X Biennial of Sao Paulo (2012) and the Architecture Academy of Mendrisio (Suiza, 2014). He is adjunct assistant professor at the School of Architecture, Pontificia Universidad Católica de Chile.

\section{DIEGO GRASS}

<dgp@030otv.com>

Architect, Pontificia Universidad Católica de Chile (2010). Co-fundador de 0зо0тv, OnArchitecture y Plan Común Arquitectos. Co-editor del libro ARQ Docs Atelier Bow-Wow (2015). He has lectured at the Arsitek Muda Indonesia (Yakarta, 2014) and the Yokohama Graduate School of Architecture (Japón, 2014 y 2015). He is adjunct assistant professor at the School of Architecture, Pontificia Universidad Católica de Chile.

\section{KIM COURREGES}

<kimcourreges@gmail.com >

Architect, Master in Architecture, Ecole d'Architecture de la Ville et des Territoires Marne-la-Vallée, France (2010). Master in Mathematics and Informatics, Paris University 7 - Denis Diderot (2005). Since 2014 she works at Elemental. In parallel she contributes to Plan Común, becoming partner in 2015

\section{MARCELO COX}

$<$ mncox@uc.cl>

Architect, Pontificia Universidad Católica de Chile (2012). TA, School of Architecture, Pontificia Universidad Católica de Chile. He works as freelance architect and associated to Plan Común Arquitectos.

\section{CLAUDIO BALADRÓN}

<claudiobaladron@gmail.com>

Architect, Pontificia Universidad Católica de Chile (2010). He works at Izquierdo Lehmann Arquitectos and as freelance associated to Magdalena Besomi.

\section{MAGDALENA BESOMI}

$<$ mbesomi@uc.cl>

Architect, Pontificia Universidad Católica de Chile (2012). Undergraduate studies at the École Polytechnique Fédéral de Lausanne, EPFL, Switzerland (2009). She is adjunct assistant professor at the School of Architecture, Pontificia Universidad Católica de Chile.

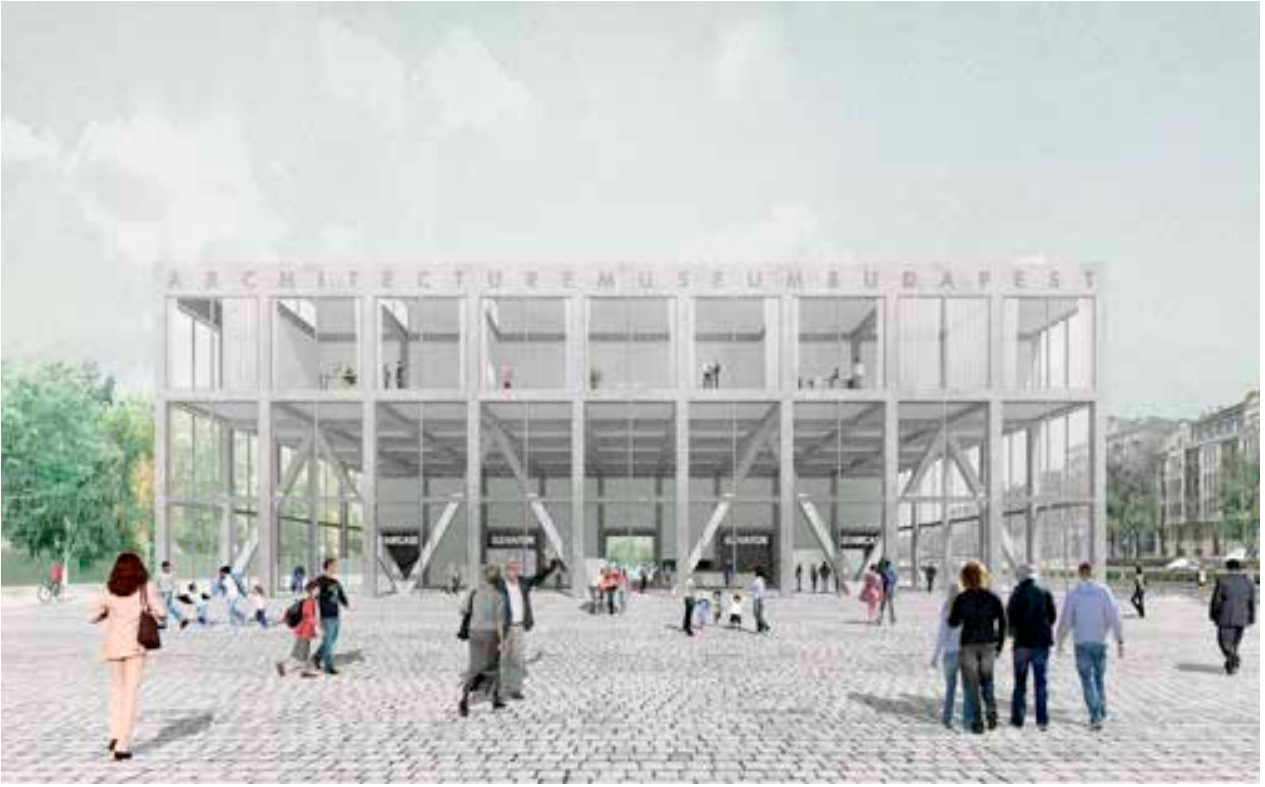

Museo de Arquitectura, vista desde plaza de acceso / Architecture Museum, view from entrance plaza

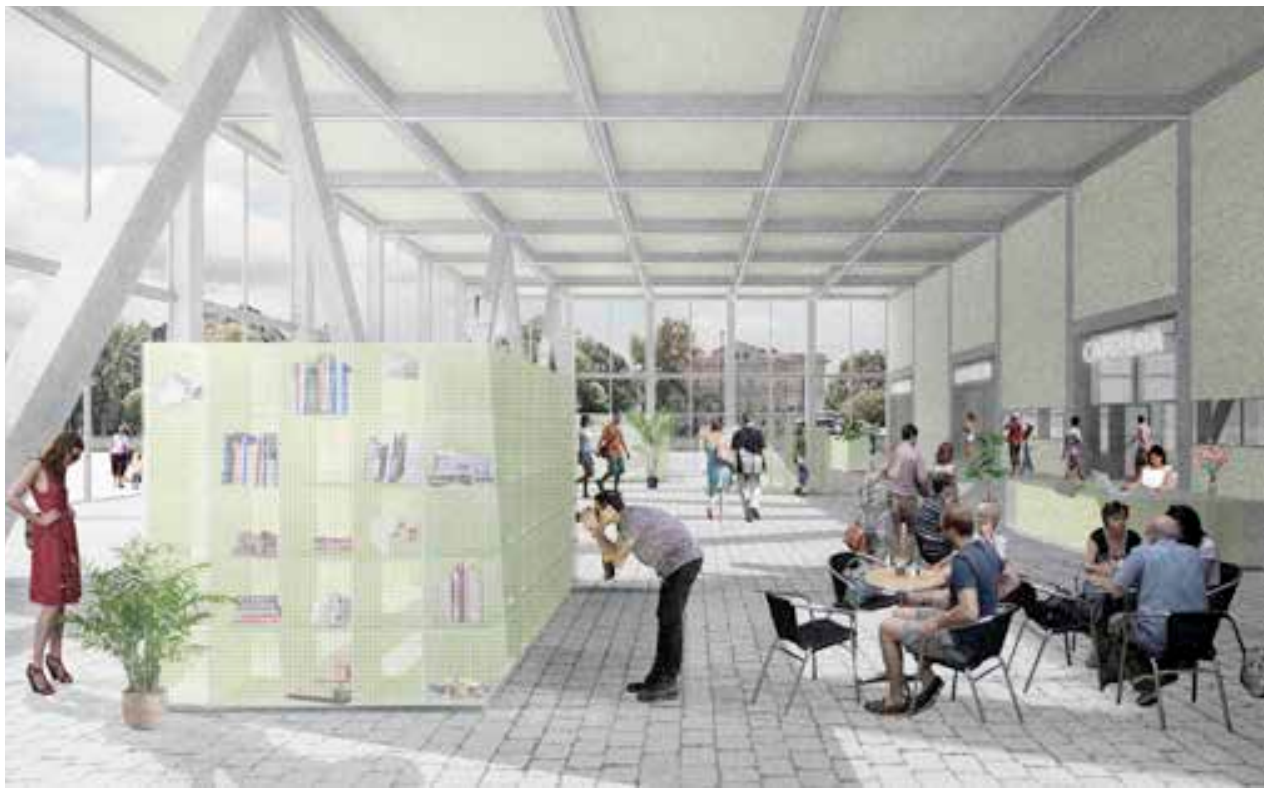

Primer nivel de uso público / First level of public use

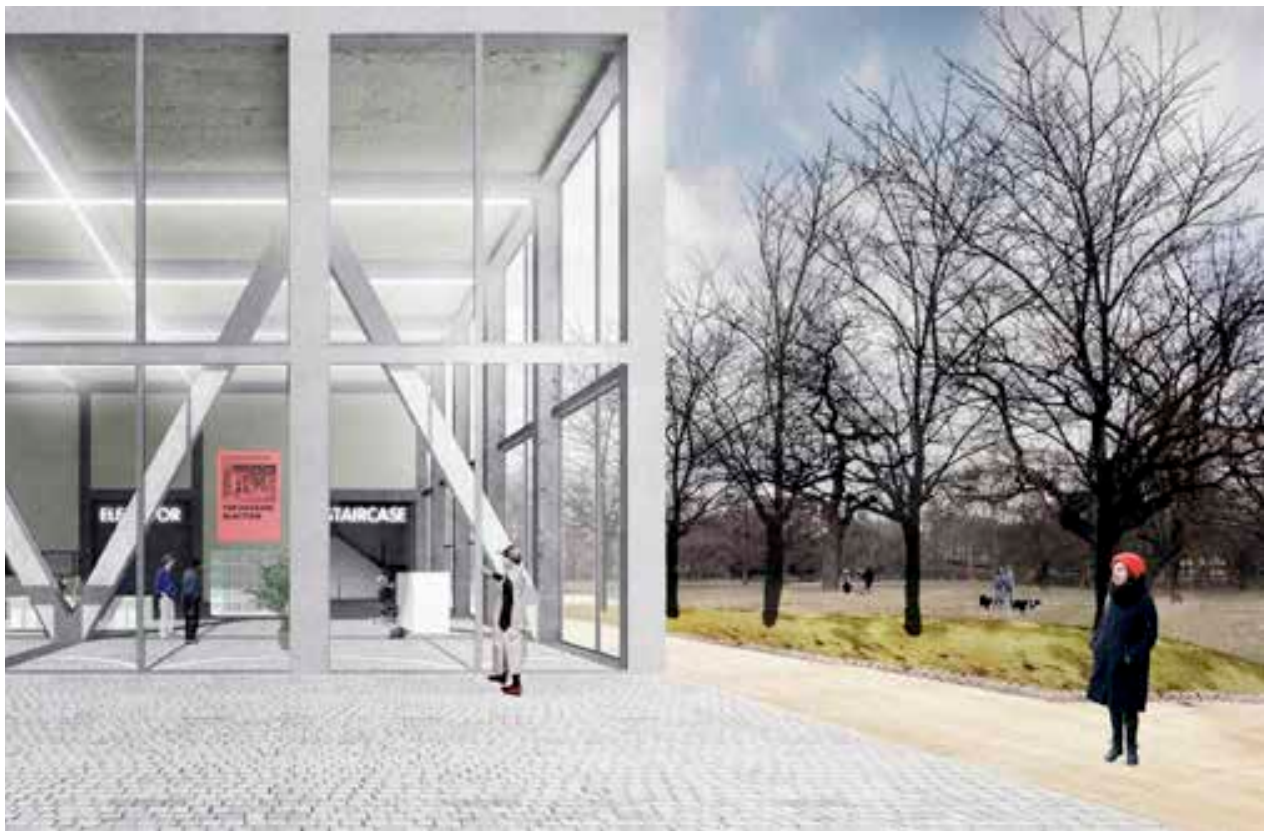

Plaza de acceso y parque / Entrance plaza and park 